\title{
Analiza językowa eponimów występujących w prawosławnej terminologii sakralnej na przykładzie wybranych ksiąg liturgicznych Kościoła prawosławnego*
}

\author{
Dariusz Kazimierowicz \\ Katedra Teologii Prawosławnej, Uniwersytet w Białymstoku, Polska \\ ORCID: 0000-0003-2333-5981 \\ d.kazimierowicz@uwb.edu.pl
}

\begin{abstract}
D. Kazimierowicz, Language analysis of eponyms occurring in Orthodox sacral terminology on the example of selected liturgical books of the Orthodox Church, Elpis, 22 2020: 121-126.

Abstract: The scope of the research in this article are eponyms and eponymic structures that are combinations of words with anthroponyms occurring in Orthodox sacred terminology. In total, 30 terms have been compiled for the purpose of language analysis. The article presents the classification of terms from the point of view of various division criteria. Thematic groups of eponyms that are combinations of words have been identified with anthroponyms within orthodox religious terminology. The collected material was subjected to linguistic analysis for the structure of syntax.

Streszczenie: Przedmiotem badań w niniejszym artykule są eponimy i konstrukcje eponimiczne będące kombinacjami słów z antroponimami występującymi w prawosławnej terminologii sakralnej. Materiał poddany analizie językowej obejmował łącznie 30 odrębnych terminów. W artykule przedstawiono klasyfikację terminów z punktu widzenia różnych kryteriów podziału. Zidentyfikowano grupy tematyczne eponimów będących kombinacjami słów z antroponimami w obrębie prawosławnej terminologii sakralnej. Zebrany materiał poddano analizie językowej pod kątem struktury i składni.
\end{abstract}

Keywords: eponym, eponymic construction, term system, term-eponym, religious lexicon, Orthodox Church lexicon, sacred and liturgical vocabulary, Orthodox vocabulary

Słowa kluczowe: eponimy, konstrukcje eponimiczne, terminologia religijna, terminologia cerkiewna, terminologia sakralno-liturgiczna, terminologia prawosławna

W terminologii wielu dzień naukowych dużą popularnością cieszą się terminy, w skład których wchodzą nazwy własne. Są to słowa, których pochodzenie w większości wiąże się z realnymi postaciami lub miejscami. Takie terminy, określone są mianem eponimów i oznaczają coś konkretnego, co jest spotykane i używane w życiu codziennym. Eponimy będąc zjawiskiem uniwersalnym, są częścią każdej terminologii, w tym także terminologii sakralnej. Ze wzglądu na rosnące zainteresowanie terminologią sakralną, wynikające m.in. z faktu, że terminologia ta przedstawia sobą zbiór pojęć mających wpływ na ważny segment życia człowieka, jakim jest sfera duchowa, chciałbym podjąć próbę analizy lingwistycznej tego zbioru wyrażeń, koncentrując swoją uwagę na eponimach będących kombinacjami słów $\mathrm{z}$ antroponimami. W mojej ocenie pozwoli to, nie tylko na lepsze zrozumienie tej sfery życia społeczeństwa, ale również przyczyni się do bardziej świadomego uczestnictwa w praktyce liturgicznej. Ponadto potrzeba podjęcia wspomnianych badań wynika również z faktu, że terminologia ta znajduje się w kręgu zainteresowań wielu podmiotów: duchownych, teologów, filozofów, kulturoznawców, religioznawców, historyków, językoznawców, a także parafian.

\footnotetext{
* Publikacja finansowana w ramach programu Ministra Nauki i Szkolnictwa Wyższego pod nazwą „Narodowy Program Rozwoju Humanistyki” w latach 2017-2022, nr projektu 0083/NPRH5/H11/84/2017.
}

Zatem przedmiotem badań niniejszego artykułu są, występujące $\mathrm{w}$ prawosławnej terminologii sakralnej, eponimy będące kombinacjami słów z antroponimami. Badania ukierunkowane są na analizę językową wspomnianej terminologii pod względem formy, struktury i składni.

Materiał badawczy do niniejszego artykułu obejmował 30 jednostek leksykalnych, które na potrzeby niniejszych badań pozyskałem z ksiąg liturgicznych Kościoła Prawosławnego: Apostoła (Apostol, 2005), Oktoichesu (Oktoih t. 1-2., 2011), Triodionu paschalnego (Triod' cvetnaâ, 2015) i Triodionu postnego (Triod' postnaâ v 2-h častâh, 2015), Euchologionu (Trebnik, 2010), Służebnika (Służebnik. Posledowanije Wieczerni i Utreni, 2001), Horologionu (Časoslov, 2009) i Modlitewnika (Polnyj pravoslavnyj molitvoslov na vsâkuû potrebu, 2010), a także Nowego Testamentu, Starego Testamentu i Psałterza (Psaltir', 2007).

Należy podkreślić, że niezwykle pomocnymi w usystematyzowaniu oraz rozszyfrowaniu znaczeń wyodrębnionych terminów okazały się następujące źródła leksykograficzne: Полный иерковнославянский словарь со внесением в него важнейтих и древнерусских слов и выражений протоиерея Григория Дьяченко (D'âčenko, 2009), Словарь иерковных терминов Дмитрия Покровского (Pokrovskij, 2002), Stownik cerkiewnostowiańsko-polski ks. Aleksego Znosko (Znosko, 1996), 
Składania Języka Cerkiewnostowiańskiego okresu nowożytnego z podręcznym stownikiem cerkiewnostowiańsko -polskim ks. Protojereja Stanisława (Eustachego) Strach (Strach, 2012), Leksyka konfesyjna w języku rosyjskim okresu radzieckiego Krzysztofa Rutkowskiego (Rutkowski, 2007), Specyfika polskiej terminologii prawostawnej pod redakcją ks. Marka Ławreszuka (Kostiuczuk, Tofiluk, Ławreszuk i inni, 2016), Liturgia prawosławna. Mały słownik Elżbiety Smykowskiej (Smykowska, 2004).

\section{Definicja eponimu}

Termin eponim wywodzi się z języka greckiego, gdzie słowo غ̇ं oraz -ónoma, co oznacza dający imię (eponim, W: Rudnicka, 2005, t. L, s. 112-116). Warto podkreślić, że istnieje wiele definicji tego pojęcia. Wielki stownik języka polskiego (eponim, W: Żmigrodzki P., Bańko M., Grochowski M. i inni, 2007) definiuje eponim jako wyraz, pochodzący od imienia danej osoby, który jest ściśle z nią związany. Inne zaś źródła i słowniki stanowią inaczej, co może świadczyć o pewnej rozbieżności. Na przykład, zgodnie ze Słownikiem mitów i tradycji kultury autorstwa Władysława Kopalińskiego (eponim, W: Kopaliński, 2003, s. 56), eponim nie oznacza nazwy, ale „osobę, której imieniem coś nazwano". Z kolei w Encyklopedii popularnej PWN można znaleźć następującą notę: ,,eponim, hist. w staroż. Atenach jeden $\mathrm{z}$ archontów, którego imieniem oznaczono rok jego urzędowania" (eponim W: Encyklopedia popularna PWN, 1982, s. 196)

Zatem eponimem nazywa się termin, który zawiera nazwę własną (antroponim, toponim lub mifonim) lub nazwę pospolitą w znaczeniu pojęcia naukowego (np. choroba Alzheimera). W innym znaczeniu eponimem może być nazwany termin utworzony od nazwy własnej (antroponim, toponim lub mifonim) poprzez przeniesienie metonimiczne (np. Ohm). Trzecią zaś grupę stanowią eponimy pochodne utworzone, od nazwy własnej (antroponimu, toponimu lub mifonimu) w sposób afiksalny.

\section{Charakterystyka strukturalna eponimów występujących w prawoslawnej terminologii sakralnej}

\section{Obszary tematyczne eponimów będących kombinacjami słów $\mathrm{z}$ antroponimami występujących w prawosławnej terminologii sakralnej}

Badany materiał obejmował 30 odrębnych jednostek leksykalnych, które zostały zakwalifikowane do następujących grup tematycznych:
- Nazwy elementów nabożeństw (8 jednostek):

Аллилуйя Радилова, Аммореовы стихиры, Анатолиевы стихиры, Богородичен, Богородичен канон, Крестобогородичен, Троичен, Херувимская песнь;

- Nazwy modlitw (4 jednostki):

Богородичное правило, Молитва Господня, Молитва Святого Ефрема Сирина, Молитва Иисусова;

- Nazwy przedmiotów (4 jednostki):

древо Иессеево, корень Иессеев, лоза Иессеева, Моисеев жезл;

- Nazwy nabożeństw (3 jednostki):

Литургия Святого Василия Великого, Литургия Святого Иоанна Златоуста, Литургия Святого Иакова Брата Господня;

- Nazwy dni (4 jednostki):

Дмитревская суббота, Лазарева суббота, Родителская суббота, Троицкая суббота;

- Nazwy inne (7 jednostek):

Авраамово недро, Адамова голова, Адамово изгнаниее, Андреево стояние, Авиева чреда, Аппиев торг, Мариино стояние.

\section{Analiza strukturalna eponimów będących kombinacjami słów $\mathrm{z}$ antroponimami występujących w prawosławnej terminologii sakralnej}

Badane terminy, $\mathrm{z}$ uwagi na budowę strukturalną, można podzielić na dwie kategorie: terminy jednowyrazowe - słowa oraz terminy wielowyrazowe - wyrażenia (Grinëv-Grinevič, 2008, s. 121).

Wśród terminów jednowyrazowych można wyróżnić trzy główne typy strukturalne:

- prste;

- afiksalne;

- złożone.

A zatem do terminów prostych zaliczane są leksemy, których temat jest zbieżny z rdzeniem. Terminy afiksalne to takie jednostki, których temat zawiera rdzeń i afiksy. Natomiast złożonymi nazywa się terminy jednowyrazowe, które zawierają w swoim składzie co najmniej dwa morfemy rdzenne (Grinëv-Grinevič, 2008, s. 121).

Uwzględniając powyższe rozróżnienie można stwierdzić, że wśród badanych w niniejszym artykule terminów jednowyrazowych wyróżniamy następujące jednostki leksykalne:

богородичен, крестобогородичен, троичен, херубикон.

Nie można pominąć kwestii, że wśród badanych terminów bardzo obszerną grupę stanowią nazwy złożone. Mogą składać się z dwóch, trzech, a często nawet $\mathrm{z}$ większej liczby komponentów. Warto zauważyć, że najczęściej wykorzystuje się kombinacje typu:

- przymiotnik + rzeczownik,

- rzeczownik + rzeczownik (z przyimkiem lub bez przyimka) (Šmelëva D.N., 1982, s. 166-167). 
W analizowanym materiale znajdujemy następujące nazwy wielowyrazowe, które przedstawione za pomocą kombinacji składających się z dwóch komponentów (16 jednostek):

Адамово изгнание, Андреево стояние, Анатолиевы стихиры, Аммореовы стихиры, Дмитревская суббота, древо Иессеево, корень Иессеев, Лазарева суббота, лоза Иессеева, Мариино стояние, молитва Господня, молитва Иисусова, Моисеев жезл, Родительская суббота, Троиикая суббота, Херувимская песнь.

Po bardziej wnikliwym przyjrzeniu się grupie badanych terminów można dojść do wniosku, że bardzo zbliżone $\mathrm{w}$ znaczeniu ogólnym do nazw dwuwyrazowych są nazwy składające się z trzech lub więcej komponentów. Jak zauważają językoznawcy, takie nazwy $\mathrm{z}$ reguły stosowane są $\mathrm{w}$ celu doprecyzowania i rozpowszechniania znaczeń nazw dwuskładnikowych. Za pomocą fraz składających się $\mathrm{z}$ trzech i więcej komponentów można szczegółowo opisywać, precyzować, a także przekazywać określone cechy gatunkowe (Šmelëva D.N., 1982, s. 169-170).

Uwzględniając liczbę elementów składowych w badanym materiale wyróżniłem następujące nazwy wielowyrazowe:

- nazwy trzywyrazowe (1 jednostka):

стояние Марии Египетской;

\section{- nazwy czterowyrazowe ( 3 jednostki):}

Литургия Святого Василия Великого, Литургия Святого Иоанна Златоустого, Молитва Святого Ефрема Сирина;

- nazwy piecciowyrazowe (1 jednostka):

Литургия Святого Иакова Брата Господня.

W poniższej tabeli przedstawiam dane liczbowe eponimów sakralnych będących kombinacjami słów z antroponimami w zależności od struktury:

\begin{tabular}{|c|c|c|c|c|c|}
\hline Rodzaje & 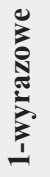 & 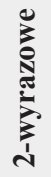 & 童 & 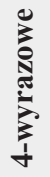 & م. \\
\hline Terminy & 4 & 16 & 1 & 3 & 1 \\
\hline Razem & & & 25 & & \\
\hline
\end{tabular}

Z przytoczonych danych wynika, że pod względem strukturalnym wśród eponimów sakralnych będących kombinacjami słów $\mathrm{z}$ antroponimami dominują nazwy dwuwyrazowe, w mniejszym stopniu stosowane są jednostki w postaci kombinacji słów o różnej liczbie komponentów. Najczęściej używaną częścią mowy przy tworzeniu eponimów sakralnych jest rzeczownik, dzięki któremu postacie, przedmioty, zjawiska i wydarzenia związane $\mathrm{z}$ terminologią sakralną otrzymują określoną nazwę.

\section{Charakterystyka składniowa}

Niewątpliwie większość terminów zazwyczaj można określić mianem pojedynczej jednostki leksykalnej, niestety nie zawsze każde z pojęć można zdefiniować jednym słowem. Niejednokrotnie, w celu doprecyzowania danego terminu, chętniej sięgamy po bardziej złożone struktury, a zatem oprócz terminów w postaci pojedynczych słów, stosujemy również kombinacje składające się z kilku komponentów.

Uwzględniając fakt, że w niniejszym artykule zdecydowaną większość badanych terminów stanowią eponimy w postaci wyrażeń, można je poddać analizie składniowej.

W wyrażeniach wyróżniamy następujące elementy:

- słowo nadrzędne (rdzeń) - słowo gramatycznie niezależne;

- słowo podrzędne - słowo uwarunkowane gramatycznie od słowa nadrzędnego.

Należy podkreślić, że wyrażenia wykazują cechy bardzo zbliżone do pojedynczych słów. Oznacza to, że wyrażenia, podobnie jak słowa, również tworzą nazwy, jednak $\mathrm{w}$ przeciwieństwie do nich stanowią nazwy złożone i jednocześnie bardziej szczegółowe, a w konsekwencji bardziej precyzyjne (Valgina N.S., 1973, s. 19-20). Ponadto omawiane struktury tworzone są zawsze w oparciu o zasadę subordynacji nadrzędnego i podrzędnego słowa, gdzie zasada, o której mowa jest już z góry określona przez semantyczną i gramatyczną strukturę wyrażenia (Valgina N.S., 1973, s. 19).

Wyrażenia klasyfikowane są według następujących kryteriów:

- struktury;

- stopnia zespolenia komponentów;

- nadrzędnego słowa.

Ze względu na liczbę elementów składowych wyrażenia dzielą się na proste i zlożone:

- Wyrażenia proste - składają się z dwóch pełnowartościowych słów, ale również należą do nich wyrażenia zawierające formy analityczne, które zawierają więcej niż jedno słowo w strukturze;

- wyrażenia złożone - składają się z więcej niż dwóch pełnowartościowych słów, które stanowią różne kombinacje prostych wyrażeń albo pojedynczego słowa i wyrażenia prostego.

W badanym materiale występują zarówno wyrażenia proste, jak i złożone:

\section{- wyrażenia proste (16 jednostek):}

Адамово изгнание, Андреево стояние, Анатолиевы стихиры, Аммореовы стихиры, Дмитревская суббота, древо Иессеево, корень Иессеев, Лазарева суббота, лоза Иессеева, Мариино стояние, молитва Господня, молитва Иисусова, Моисеев жезл, Родительская суббота, Троицкая суббота, Херувимская песнь.

\section{- wyrażenia złożone (5 jednostek):}

Литургия Святого Василия Великого, Литургия Святого Иоанна Златоуста, Литургия Святого Иакова Брата Господня, Молитва Святого Ефрема Сирина, Стояние Марии Египетской.

Poniżej przedstawiam charakterystykę badanych terminów: 
a) wyrażenia proste

\begin{tabular}{|c|c|c|c|}
\hline Wyrażenie/Związek wyrazowy & Typ wyrażenia & Relacja & $\begin{array}{c}\text { Rodzaj związku } \\
\text { skladniowego }\end{array}$ \\
\hline Авиева чреда & $\begin{array}{c}\text { wyrażenie o postaci grupy } \\
\text { imiennej } \\
\text { z przymiotnikiem }\end{array}$ & określająca & związek zgody \\
\hline Адамово изгнание & $\begin{array}{c}\text { wyrażenie o postaci grupy } \\
\text { imiennej } \\
\text { z przymiotnikiem }\end{array}$ & określająca & związek zgody \\
\hline Андреево стояние & $\begin{array}{c}\text { wyrażenie o postaci grupy } \\
\text { imiennej } \\
\text { z przymiotnikiem }\end{array}$ & określająca & związek zgody \\
\hline Анатолиевы стихиры & $\begin{array}{c}\text { wyrażenie o postaci grupy } \\
\text { imiennej } \\
\text { z przymiotnikiem }\end{array}$ & określająca & związek zgody \\
\hline Аммореовы стихиры & $\begin{array}{c}\text { wyrażenie o postaci grupy } \\
\text { imiennej } \\
\text { z przymiotnikiem }\end{array}$ & określająca & związek zgody \\
\hline Аппиев торг & $\begin{array}{c}\text { wyrażenie o postaci grupy } \\
\text { imiennej } \\
\text { z przymiotnikiem }\end{array}$ & określająca & związek zgody \\
\hline Дмитревская суббота & $\begin{array}{c}\text { wyrażenie o postaci grupy } \\
\text { imiennej } \\
\text { z przymiotnikiem }\end{array}$ & określająca & związek zgody \\
\hline древо Иессеево & $\begin{array}{c}\text { wyrażenie o postaci grupy } \\
\text { imiennej } \\
\text { z przymiotnikiem }\end{array}$ & określająca & związek zgody \\
\hline корень Иессеев & $\begin{array}{l}\text { wyrażenie o postaci grupy } \\
\text { imiennej } \\
\text { z przymiotnikiem }\end{array}$ & określająca & związek zgody \\
\hline Лазарева суббота & $\begin{array}{c}\text { wyrażenie o postaci grupy } \\
\text { imiennej } \\
\text { z przymiotnikiem }\end{array}$ & określająca & związek zgody \\
\hline лоза Иессеева & $\begin{array}{c}\text { wyrażenie o postaci grupy } \\
\text { imiennej } \\
\text { z przymiotnikiem }\end{array}$ & określająca & związek zgody \\
\hline Мариино стояние & $\begin{array}{c}\text { wyrażenie o postaci grupy } \\
\text { imiennej } \\
\text { z przymiotnikiem }\end{array}$ & określająca & związek zgody \\
\hline молитва Господня & $\begin{array}{c}\text { wyrażenie o postaci grupy } \\
\text { imiennej } \\
\text { z przymiotnikiem }\end{array}$ & określająca & związek zgody \\
\hline молитва Иисусова & $\begin{array}{c}\text { wyrażenie o postaci grupy } \\
\text { imiennej } \\
\text { z przymiotnikiem } \\
\text { прилагательным }\end{array}$ & określająca & związek zgody \\
\hline Моисеев жезл & $\begin{array}{c}\text { wyrażenie o postaci grupy } \\
\text { imiennej } \\
\text { z przymiotnikiem }\end{array}$ & określająca & związek zgody \\
\hline Родительская суббота & $\begin{array}{c}\text { wyrażenie o postaci grupy } \\
\text { imiennej } \\
\text { z przymiotnikiem }\end{array}$ & określająca & związek zgody \\
\hline Троицкая суббота & $\begin{array}{c}\text { wyrażenie o postaci grupy } \\
\text { imiennej } \\
\text { z przymiotnikiem }\end{array}$ & określająca & związek zgody \\
\hline Херувимская песнь & $\begin{array}{c}\text { wyrażenie o postaci grupy } \\
\text { imiennej } \\
\text { z przymiotnikiem }\end{array}$ & określająca & związek zgody \\
\hline
\end{tabular}


Analizując dane z tabeli można stwierdzić, że wyrażenia proste przedstawiają jeden typ, w którym słowem nadrzędnym jest rzeczownik, podrzędnym zaś przymiotnik.
Między tymi komponentami występują relacje określające i związek zgody składniowej.

b) wyrażenia złożone

\begin{tabular}{|c|c|c|c|c|}
\hline Wyrażenie złożone & $\begin{array}{l}\text { Wyrażenie } \\
\text { proste }\end{array}$ & Typ wyrażenia & Relacja & Rodzaj związku \\
\hline $\begin{array}{l}\text { Литургия Святого } \\
\text { Василия Великого }\end{array}$ & $\begin{array}{l}\text { 1. Литургия Василия } \\
\text { 2. Святого Василия } \\
\text { 3. Василия Великого }\end{array}$ & $\begin{array}{l}\text { 1. wyrażenie o postaci grupy } \\
\text { imiennej z rzeczownikiem } \\
\text { 2. wyrażenie o postaci grupy } \\
\text { imiennej z przymiotnikiem } \\
\text { 3. wyrażenie o postaci grupy } \\
\text { imiennej z przymiotnikiem }\end{array}$ & $\begin{array}{l}\text { 1. określająca } \\
\text { 2. określająca } \\
\text { 3. określająca }\end{array}$ & $\begin{array}{l}\text { 1. związek rządu } \\
\text { 2. związek zgody } \\
\text { 3. związek zgody }\end{array}$ \\
\hline $\begin{array}{c}\text { Литургия Святого } \\
\text { Иоанна Златоустого }\end{array}$ & $\begin{array}{l}\text { 1. Литургия Иоанна } \\
\text { 2. Святого Иоанна } \\
\text { 3. Иоанна Златоустого }\end{array}$ & $\begin{array}{l}\text { 1. wyrażenie o postaci grupy } \\
\text { imiennej z rzeczownikiem } \\
\text { 2. wyrażenie o postaci grupy } \\
\text { imiennej z przymiotnikiem } \\
\text { 3. wyrażenie o postaci grupy } \\
\text { imiennej z przymiotnikiem }\end{array}$ & $\begin{array}{l}\text { 1. określająca } \\
\text { 2. określająca } \\
\text { 3. określająca }\end{array}$ & $\begin{array}{l}\text { 1. związek rządu } \\
\text { 2. związek zgody } \\
\text { 3. związek zgody }\end{array}$ \\
\hline $\begin{array}{c}\text { Литургия Святого } \\
\text { Иакова Брата } \\
\text { Господня }\end{array}$ & $\begin{array}{l}\text { 1. Литургия Иакова } \\
\text { 2. Святого Иакова } \\
\text { 3. Брата Господня }\end{array}$ & $\begin{array}{l}\text { 1. wyrażenie o postaci grupy } \\
\text { imiennej z rzeczownikiem } \\
\text { 2. wyrażenie o postaci grupy } \\
\text { imiennej z przymiotnikiem } \\
\text { 3. wyrażenie o postaci grupy } \\
\text { imiennej z przymiotnikiem }\end{array}$ & $\begin{array}{l}\text { 1. określająca } \\
\text { 2. określająca } \\
\text { 3. określająca }\end{array}$ & $\begin{array}{l}\text { 1. związek rządu } \\
\text { 2. związek zgody } \\
\text { 3. związek zgody }\end{array}$ \\
\hline $\begin{array}{c}\text { Молитва Святого } \\
\text { Ефрема Сирина }\end{array}$ & $\begin{array}{l}\text { 1. Молитва Ефрема } \\
\text { 2. Святого Ефрема } \\
\text { 3. Ефрема Сирина }\end{array}$ & $\begin{array}{l}\text { 1. wyrażenie o postaci grupy } \\
\text { imiennej z rzeczownikiem } \\
\text { 2. wyrażenie o postaci grupy } \\
\text { imiennej z przymiotnikiem } \\
\text { 3. wyrażenie o postaci grupy } \\
\text { imiennej z rzeczownikiem }\end{array}$ & $\begin{array}{l}\text { 1. określająca } \\
\text { 2. określająca } \\
\text { 3. określająca }\end{array}$ & $\begin{array}{l}\text { 1. związek rządu } \\
\text { 2. związek zgody } \\
\text { 3. związek zgody }\end{array}$ \\
\hline $\begin{array}{c}\text { Стояние Марии } \\
\text { Египетской }\end{array}$ & $\begin{array}{l}\text { 1. Стояние Марии } \\
\text { 2. Марии Египетской }\end{array}$ & $\begin{array}{l}\text { 1. wyrażenie o postaci grupy } \\
\text { imiennej z rzeczownikiem } \\
\text { 2. wyrażenie o postaci grupy } \\
\text { imiennej z przymiotnikiem }\end{array}$ & $\begin{array}{l}\text { 1. określająca } \\
\text { 2. określająca }\end{array}$ & $\begin{array}{l}\text { 1. związek rządu } \\
\text { 2. związek zgody }\end{array}$ \\
\hline
\end{tabular}

Z przeprowadzonej analizy składniowej wyrażeń złożonych dotyczących prawosławnej terminologii sakralnej wynika, że używane są w nich przede wszystkim rzeczowniki i przymiotniki. We wszystkich badanych jednostkach między komponentami występują relacje określające. Stosuje się również rodzaje łączności podporządkowanej, a mianowicie związek zgody lub rządu.

\section{Zakończenie}

Bez wątpienia eponimy stanowią niezwykle przydatny sposób na wzbogacanie leksyki. Ich uniwersalność i obec- ność niemal w każdej dziedzinie życia sprawia, że często zapominamy albo nie zdajemy sobie sprawy, że przed chwilą użyliśmy właśnie eponimu.

Analiza językowa badanych eponimów w niniejszym artykule pozwoliła nie tylko zapoznać się z częścią prawosławnej terminologii sakralnej, ale także zwrócić szczególną uwagę na imiona postaci charakterystycznych dla prawosławnego dyskursu religijnego.

\section{Bibliografia}

Apostol. (2005). Kiev: Ukrainskaâ Pravoslavnaâ Cerkov'. Kievskaâ mitropoliâ [Апостол. (2005). Киев: Украинская Православная Церковь. Киевская Митрополия].

Časoslov. (2009). Moskva: Izdatel'stvo Moskovskoj Patriarhii. [Часослов. (2009). Москва: Издательство Московской Патриархии].

D'âčenko, G.M. (2009). Polnyjcerkovnoslavânskij slovar's vneseniem $v$ nego važnejših drevnerusskih slov $i$ vyraženij,
Moskva [Дьяченко, Г.М. (2009). Полный иерковнославянский словарь с внесением в него важнейших древнерусских слов и выражений. Москва].

Grinëv-Grinevič, S. V. (2008). Terminovedenie. Moskva [Гринёв-Гриневич, С. В. (2008). Терминоведение. Москва].

Kopaliński, W. (2003). Słownik mitów i tradycji kultury. Warszawa. 
Kostiuczuk, J., Tofiluk J., Ławreszuk, M., Misijuk, W., Charkiewicz, J. (2016). Specyfika polskiej terminologii prawosławnej. Białystok: Wydawnictwo Uniwersytetu w Białymstoku.

Marcinowski, R. (red.). Encyklopedia popularna PWN. (1982). Warszawa.

Oktoih t. 1-2. (2011). Kiev: Ukrainskaâ Pravoslavnaâ Cerkov'. Kievskaâ Mitropoliâ [Oкmoux t. 1-2. (2011). Киев: Украинская Православная Церковь. Киевская Митрополия.

Pokrovskij, D. (2002). Slovar'cerkovnyh terminov. Izographstudio. [Покровский, Д. (2002). Словарь церковных терминов. IzographStudio].

Polnyj pravoslavnyjmolitvoslov na vsâkuû potrebu. (2010). Svâto-Uspenskaâ Počaevskaâ Lavra [Полный православный молитвослов на всякую потребу. (2010). Свято-Успенская Почаевская Лавра].

Psaltir. (2007). Moskva: Izdatel'skijsovet Russkoj Pravoslavnoj Cerkvi [Псалтир. (2007). Москва: Издательский Совет Русской Православной Церкви].

Rudnicka, E. (2005). Z pogranicza leksykologii i onomastyki. Przyczynek terminologiczny. W: „Prace filologiczne” (t. L. s. 112-116).

Rutkowski, K. (2007). Leksyka konfesyjna w języku rosyjskim okresu radzieckiego. Białystok: Wydawnictwo Uniwersytetu w Białymstoku.

Stużebnik. Posledowanije Wieczerni i Utreni. (2001). Warszawa: Metropolia Prawosławna.
Smykowska, E. (2004). Liturgia prawosławna. Mały słownik. Warszawa.

Šmelëva, D.N. (red.). (1982). Sposoby nominacii v sovremennom russkom âzyke. Moskva. [Шмелёва, Д.Н. (red.). (1982). Способы номинации в современном русском языке. Москва].

Strach, S. (2012). Składania języka Cerkiewnosłowiańskiego okresu nowożytnego z podręcznym słownikiem cerkiewnosłowiańsko-polskim. Ząbkowice Śląskie.

Trebnik. (2010). Warszawa: Warszawska metropolia Prawosławna. [Требник. (2010). Warszawa: Warszawska Metropolia Prawosławna].

Triod' cvetnaâ. (2015). Kiev: Ukrainskaâ Pravoslavnaâ Cerkov', Kievskaâ Mitropoliâ [Триодь ц̧ветная. (2015). Киев: Украинская Православная Церковь, Киевская Митрополия].

Triod'postnaâ v 2-h častâh. (2015). Moskva: Izdatel'stvo Moskovskoj Patriarhii. [Триодь Постная в 2-х частях. (2015). Москва: Издательство Московской Патриархии].

Valgina, N.S. (1973). Sintaksis sovremennogo russkogo âzyka. Moskva [Валгина, Н.С. (1973). Синтаксис современного русского языка. Москва].

Znosko, A. (1996). Słownik cerkiewnosłowiańsko-polski. Białystok.

Żmigrodzki, P., Bańko M., Grochowski, M., Kowalik, W., Przybylska, R. (2007). Wielki słownik języka polskiego. Warszawa. 